\title{
Şilöz asitle prezente olan taşlı yüzük hücreli mide kanseri
}

\author{
Chylous ascites as a form of presentation of signet ring cell carcinoma of the stomach
}

Mesut SEZIKLİ ${ }^{1}$, Züleyha AKKAN ÇETINKAYA ${ }^{1}$, Fatih GÜZELBULUT², Hayrünnisa SEZIKLI ${ }^{3}$, Selvinaz ÖZKARA ${ }^{4}$, Göktuğ ŞIRIN ${ }^{1}$

Kocaeli Derince Eğitim Araştırma Hastanesi, ${ }^{1}$ Gastroenteroloji Kliniği ve ${ }^{3}$ Biyokimya Kliniği, Kocaeli

Elazığ Eğitim Araştırma Hastanesi, ${ }^{2}$ Gastroenteroloji Kliniği, Elazı̆̆

Haydarpaşa Numune Eğitim Araştırma Hastanesi, ${ }^{4}$ Patoloji Kliniği, Istanbul

Silöz asit siroza bağlı tüm asitlerin \%0,5'ini ve tüm malign asitlerin \%1'den daha azını oluşturan nadir bir asit şeklidir. Asit tetkikinin ilk basamağı olan görünümde fark edilen süt rengi değişiklik ve mayi trigliserit düzeyi bizi șilöz asit tanısına götürür. Fakat altta yatan nedeni bulmak çoğunlukla zorluk arz edebilir. Biz batında şişlik şikayeti ile gelen ve şilöz asit saptanan batın ve toraks tomografisi, gastroskopi ile değil de perikard sıvisında metastatik taşh yüzük hücreli kanseri tanısı alan ve kontrol gastroskopisinde gastrik patoloji saptanan bir olguyu sunmayı amaçladık.

Anahtar kelimeler: Şilöz asit, taşlı yüzük hücreli karsinom
Chylous ascites is a rare type of ascites, constituting $0.5 \%$ of all cases and less than $1 \%$ of malignant ascites. Diagnosis of chylous ascites is revealed by the milky appearance of the fluid on gross examination and high triglyceride levels on biochemical analysis. However, identifying the cause of chylous ascites is usually difficult. In this report, we present a male patient who admitted to the hospital with ascites. Biochemical evaluation of the fluid revealed chylous ascites. The diagnosis of signet ring cell gastric adenocarcinoma was made by upper gastrointestinal endoscopy and biopsy after establishing metastasis to the pericardium, despite normal findings on chest and abdomen tomography.

Key words: Chylous ascites, signet ring cell carcinoma of the stomach

\section{GİISS}

Şilöz asit siroza bağlı tüm asitlerin \%0,5’ini ve tüm malign asitlerin \%l'den daha azını oluşturan nadir bir asit şeklidir. Asit tetkikinin ilk basamağı olan görünümde fark edilen süt rengi değişiklik ve mayi trigliserit düzeyi bizi şilöz asit tanısına götürür. Fakat altta yatan nedeni bulmak çoğunlukla zorluk arz edebilir. Biz batında şişlik şikayeti ile gelen ve şilöz asit saptanan batın ve toraks tomografisi, gastroskopi ile değil de perikard sıvısında metastatik taşlı yüzük hücreli kanseri tanisı alan ve kontrol gastroskopisinde gastrik patoloji saptanan bir olguyu sunmayı amaçladık.

\section{OLGU}

Kırksekiz yaşında market işleticisi olarak çalışan hasta çevre bir hastaneden 1 ay süreli yatış sonrası şilöz asit etiyoloji bulunamaması üzerine merkezimize sevk edildi. 4 ay önce karında şişlik fark eden hastaya gittiği sağlik merkezinde gaz giderici verilmiş, hasta bu tedaviden fayda görmeyince başvurduğu hastanede yattığı dönemde karnından yaklaşık 24 litre sıvı alınmış. Tetkiklerinde şilöz asit olduğu saptanmış. Gastroskopisinde duodenum 2. kısımda beyaz milimetrik plaklar izlenmiş, kolonoskopisi ise normalmiş. Görüntüleme teknikleri ile de tanı konulamayınca hasta tarafımıza sevk edilmiş. Anamnezinde 14 yıl önce toraks travmalı trafik kazası öyküsü mevcut, fakat yakın zamanda travma, radyoterapi öyküsü yoktu.
Fizik muayenesinde sağ hemitoraksta gögüs tüpü vardı. Her iki hemitoraks bazalde solunum sesleri azalmıştı. Batında yogun asit mevcuttu. Alt ekstremitede bilateral pretibal ödem mevcuttu.

Hastaya yatışı sonrası parasentez tekrarlandı. Şilöz asitle uyumlu geldi (Trigliserit>1600MG/DL). Toraks sıvısı şilöz karakterde değildi. Batında lenf sistemine bası yapabilecek patoloji açısından batın bilgisayarlı tomografi (BT) tekrarlandı, patoloji saptanmadı. Tüberküloz testi (PPD ve quantiferon testi) negatif olarak değerlendirildi. Hastaya gastroskopi işlemi hastanemizde tekrar yapıldı. Mide mukoza ve lümeninde bir patoloji saptanmadı (Resim 1). Şilöz asit etiyolojisine yönelik olası intraabdominal lenf sistemi patolojisi açısından lenfosintigrafi yapıldı. 4 saat süren görüntülemede pelvik bölgede obstrüksiyon düşündürecek şekilde batın içine minimal geçiş izlendi. Konstrüktif perikardit vb. kardiyak patoloji açısından kardiyolojik değerlendirme yapıldı. Yapılan ekokardiografi ile kardiyolojik bir neden saptanmadı. Hastaya kalıcı batın katateri ve oral beslenmesi tamamen kesip total parenteral nütrisyon (TPN) ile beslenmeye geçilmesi düşünüldü. Hastaya diyet + sandostatin $(0,1 \mathrm{mg} 1 \mathrm{xl}$ sc) başlandı. Şilöz asit azalmaya başladı. Günlük gelen miktarı 100 cc'ye kadar düştü. Batın ve toraks BT kontrolü önerildi. Yapılan toraks BT'de perikardın kalın olduğu ve konstrüktif perikarditin dü- 
şünülmesi gerektiği şeklinde raporlandı. Uzmanlar arası uyumsuzluk riski nedeni ile hastaya farklı kardiyoloji merkezinde tekrar ekokardiyografi yapildı. Yapilan ekokardiyografisinde kalp sol lateral-apeks kısmında yaklaşık 3-3,5 cm'lik infiltratif sıvı koleksiyonu saptandı. Bu alandan biyopsi yapıld. Patoloji sonucu plevra ve perikard mayide taşlı yüzük hücreli karsinom olarak raporlandı. Bunun üzerine primeri araştırmak için tekrar gastroduodenoskopi işlemi yapıldı. Küçük kurvaturanın insusura tarafında yaklaşık 5-7 mm'lik üzeri beyaz eksudalı ülsere alan izlendi (Resim 2).Alınan biyopsi sonucu taşlı yüzük hücreli karsinomla uyumlu geldi.

\section{TARTISMA}

Batın içinde lipitten zengin lenf birikmesi ile karakterize şilöz asit ilk defa 169l'de Morton tarafından tariflenmiştir (1). Şilöz asit siroza bağlı tüm asitlerin \%0,5'ini ve tüm malign asitlerin \% l'den daha azını oluşturan nadir bir asit şeklidir (2). Şilöz asit nedenleri Tablo l'de özetlenmiştir (3-6). Asit tetkikinin ilk basamağı olan görünümde fark edilen süt rengi değişiklik ve mayi trigliserit düzeyi bizi şilöz asit tanısına götürür. Fakat sebep olan patolojiyi bulmak zorluk arz edebilir.

Barsak kapillerlerinden başlayan lenf sisteminde duktus torasikusa kadar olan her hangi bir yerdeki tıkanıklık veya kaçakta şilöz asit oluşabilir. Kapiller seviyede intestinal lenfanjiektazi olabileceği gibi daha ileride olan bir obstrüksiyonda da basınç artışına bağlı kapiller genişlemeler olabilir. Hastamızın gastroskopisinde duodenum 2. kısımda görülen beyaz plaklar bu şekilde açılklanabilir.

Hastamız bize belli bir noktaya kadar araştırılarak gelmişti. Her ne kadar şilöz asit nedenlerinde sirotik asit en önde gelen nedenlerden biri olarak bildirilse de siroza bağlı asitlerde lenf kaçağına ek olarak portal hipertansif asit de olur ve trigliserid miktarı yüksek değerlere ulaşmaz (7). Ayrıca hastamızda karaciğer sirozu düşündürebilecek öykü, fizik muayene ve laboratuvar bulguları mevcut değildi. Diğer en sik neden travma öykü ile ekarte edildi. Şilöz asit nedenlerinden sık rastlanan diğer bir klinik ise batın içi malignitelerdir. Başta lenfoma olmak üzere over, kolon, renal, prostat, gastrik, pankreas ve testis tümörleri lenfatik obstrüksiyona neden olarak şilöz asit yapabilirler. Gerek tomografik görüntüler gerekse de laboratuvar sonuçları bize her zaman yardımcı olmayabilir. Hastamızda 3 ayda toplam 3 defa çekilen batın tomografisinde malignite lehine bulgu yoktu. Lenfosintigrafide görülen minimal geçişi batındaki yoğun asite bağlı olabileceği şeklinde yorumladık. Çünkü portal sistemin döküldügü lenf siteminin anatomik olarak daha distalde olan bir tıkanıklıkla hastada şilöz asitten ziyade alt ekstremitede lenfödem olmasını beklerdik. $\mathrm{Bu}$ nedenle sintigrafide ön görülen pelvis patolojisinden uzaklaştık. Hastamızın torakstaki mayisinin şilöz karakterde olmayışı muhtemel lenf sistemine bası yapan lezyonun diafragma alt bölgesinde ana lenf -ven-arter bölgesine yakın bir
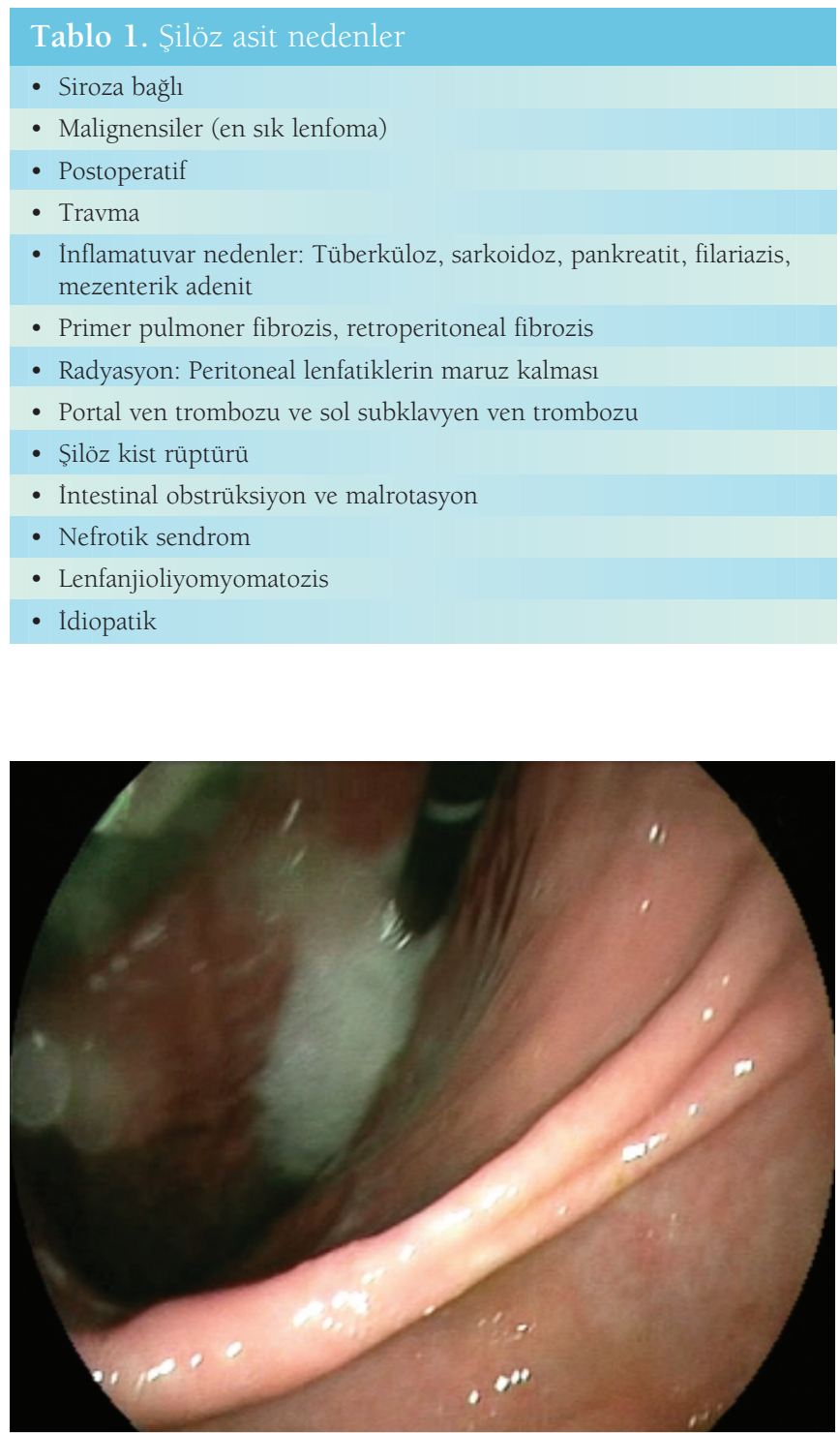

Resim 1. Insusura proksimalinin ilk yatış dönemindeki görünümü

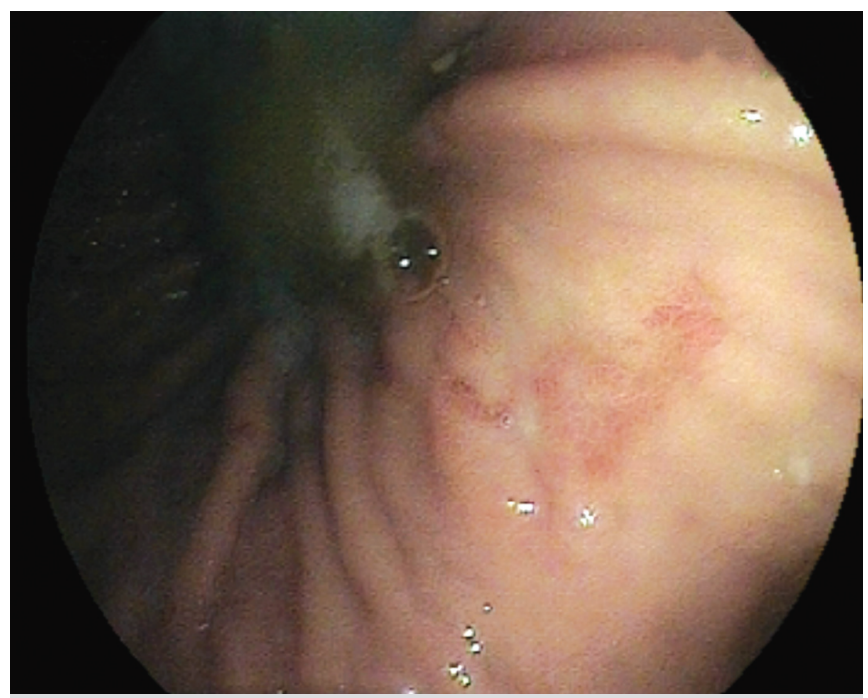

Resim 2. Insusura proksimali, büyük kurvaturada 3-5 mm çaplı ülser 
yerde olduğu düşündürdü. Dış merkezde yapılan gastroskopi normal olarak raporlanmıştı. Kontrol amaçlı servisimizde ilk yapılan gastroskopi de normal olarak raporlanmıştı (Resim 1). Kontrol toraks tomografisindeki perikard kalınlaşması bölgesinden yapılan biyopsi ile taşlı yüzük hücreli karsinom tanısı aldı. Taşlı yüzük hücreli karsinom adenokarsinomların bir çeşiti olup patolojik olarak hücrelerde yoğun musin ve buna bağlı çekirdeğinin hücre köşesine itilmesi ile karekterizedir. Adenokanser gelişebilecek tüm dokularda olmakla birlikte en sık midede görülür. Fakat şilöz asit ile prezantasyonu oldukça nadirdir. Literatürde batında ve toraksta şilöz asit ile prezente olan vaka bazında yayınlar vardır $(8,9)$. Bu bilgiler ışığında 3. kere yapılan gastroskopisindeki saptanan ülser rutin uygulamalarda gözden kaçabilecek türde idi (Resim 2).

Gastrik adenokarsinomların klasik prezantasyonu kilo kaybı ve devam eden karın ağrısıdır (10). Hastalar nadiren uzak metastaz bulguları ile başvurabilir. En sık metastaz bölgeleri

\section{KAYNAKLAR}

1. Bowse NL, Wilson NM, Russo F, et al. Aetiology and treatment of chylous ascites. Br J Surg 1992;79:1145-50.

2. Lyche KD: Miscellaneous diseases of the peritoneum and mesentry. In: Current Diagnosis \& Treatment in Gastroenterology. (Eds) Grendell JH, McQuaid KR, Friedman SL. Appleton \&Lange A Simon \& Schuster Company $199: 143-4$

3. Runyon BA: Ascites and Spontaneous Bacterial Peritonitis. In: Sleisenger and Fordtran's Gastrointestinal and Liver Disease. (Eds) Feldman M, Scharschmidt BF, Sleisenger MH. Sixth Edition. WB Saunders Company, Philadelphia, 1998;1320.

4. Caldmell SH, Battle EH. Ascites and Spontaneous Bacterial Peritonitis. In:Schiff's Diseases of the Liver. (Eds) Schiff ER, Sorrell MF, Maddrey WC. Eighth Edition. Lippincott Williams \& Wilkins, 227 East Washington Square Philadelphia. 1999;508.

5. Ablan JC, Littooy FN, Freeark RJ. Postoperative chylous ascites: Diagnosis and Treatment. A series report and literature review. Arch Surg 1990;125:270-3. karaciğer, peritoneal yüzeyler ve bölgesel ya da uzak lenf bezleridir. Asit peritoneal karsinomatosisin ilk belirtisi olabilir. Asitin malign karakterde olmasını bekleriz. Bu hastamızda ise şilöz karakerde idi. Asit mayide yüksek oranda bulunan trigliserit düzeyi diğer değerlerin sağlıklı ölçülmesini engelledi. Hastadaki taşlı yüzük hücreli kanserin mide lümenine doğru büyümediği için ilk gastroskopilerde patoloji izlenmediğini düşündük. Hatta son tanı konan gastroskopide bile görünüm tipik ileri evre metastatik bir gastrik kanser görünümünde değildi (Resim 2). Tomografideki negatifliği ise çekim kalitesine batındaki yoğun asite ve değerlendiriciye bağlayabiliriz.

Şilöz asit nadir görülen klinik bulgulardan olup etiyolojisine ulaşmak çoğu zaman bizim vakamızda da olduğu gibi zordur. Tanı esnasındaki her sonuca -tıbbın her dalında olduğu gibişüphe ile bakmalı ve ekartasyon kriterlerimizi mümkün oldugunca daraltmalıyı.

6. Kelly J, Moss J. Lymphangioleiomyomatosis. Am J Med Sci 2001;321:1725 .

7. Laterre PF, Dugernier T, Reynaert MS.Chylous ascites: diagnosis, causes and treatment. Acta Gastroenterol Belg 2000;63:260-3.

8. Bellot García V, Guilarte López-Mañas J, Fernández Pérez R, et al. Chylous ascites and chylothorax as the initial manifestation of a gastric adenocarcinoma. Gastroenterol Hepatol 1997;20:383-4.

9. Miwa M, Kasamatsu N, Shibata M, et al. [A case of gastric cancer with bilateral chylothorax]. Nihon Kokyuki Gakkai Zasshi. 2009;47:1115-9.

10. Wanebo HJ, Kennedy BJ, Chmiel J, et al. Cancer of the stomach. A patient care study by the American College of Surgeons. Ann Surg 1993;218:583-92. 